Article

\title{
Environmental Assessment of Amylase Used as Digestibility Improvement Factor for Intensive Chicken Production in Brazil
}

\author{
Britta Gernaey ${ }^{1, *}$, José Otávio B. Sorbara ${ }^{2}$ and Per H. Nielsen ${ }^{1}$ \\ 1 Novozymes A/S, 2880 Bagsværd, Denmark; phgn@novozymes.com \\ 2 DSM Nutritional Products A/S, 4302 Kaiseraugst, Switzerland; jose-otavio.sorbara@dsm.com \\ * Correspondence: brpt@novozymes.com; Tel.: +45-44-460000
}

Received: 22 May 2018; Accepted: 14 July 2018; Published: 3 August 2018

\begin{abstract}
Industrial enzymes can be used to improve the digestibility of livestock feed components, thereby increasing the nutritional value of the feed, and allowing farmers to change and cost-optimize the feed composition. The purpose of this study was to investigate the environmental impacts of adding a starch-degrading enzyme (amylase) to feed for Brazilian chicken production. A lifecycle assessment covering all significant processes in the value chain as well as all significant impact categories was used as analytical tool. The application of amylase increases the energy value of corn in chicken feed and allows saving of costly fat in the feed. In Brazil, the saved fat is used either for biodiesel production or as a replacement for other fats in cleaning and hygiene products. The study showed that approximately $6 \%$ of greenhouse-gas emission from Brazilian chicken production could be avoided using the amylase. Using the amylase increases the contribution to nutrient enrichment by $0.6 \%$ when the excess fat is used for biodiesel. The use of amylase has little impact on agricultural land use, water consumption and acidification.
\end{abstract}

Keywords: life cycle assessment; LCA; environment; enzyme; amylase; feed; chicken; broiler

\section{Introduction}

It is well established that livestock production is a major source of environmental impact due to feed production, enteric emissions, and emissions from manure [1]. It has, for instance, been estimated that livestock production is responsible for $14.5 \%$ of human-induced greenhouse-gas emissions [2]. Animal production is expected to grow in the coming years due to population growth and improved economy in many places [3], and there is a great need to decouple growth in production and impact on the environment. MacLeod et al. [4] have studied greenhouse-gas emissions from the pig and chicken supply chains in a life-cycle perspective and have proposed a range of means to reduce the impact on the climate. One suggestion is to improve feed conversion of the individual animal.

Enzymes are biological catalysts that can bring biochemical reactions to their equilibriums faster than this would otherwise occur [5]. Enzymes have been used to produce goods for human consumption for at least 2000 years [6]. Enzymes are now produced by microbial fermentation and have proven to be environmentally advantageous over conventional processes in a broad range of industries [7].

Animals' own enzyme systems are not sufficient to allow for full utilization of all constituents of the feed, and supplementation of specialized feed enzymes can be used to improve feed conversion [8]. This benefits farmers because costly feed ingredients can be saved and, at least in some cases, it benefits the environment because less feed needs to be produced and fewer polluting compounds are escaping stables and manure deposits. 
There are four main groups of enzymes for animals: phytic-acid-degrading enzymes (phytases), protein-degrading enzymes (proteases), fiber-degrading enzymes (e.g., xylanases) and starchdegrading enzymes (amylases) [8]. Nielsen and Wenzel [9] have demonstrated the environmental benefits of phytase use in intensive pig production because inorganic phosphorus supplementation to the pigs' feed was reduced. Oxenbøll et al. [10] and Leinonen and Williams [11] have demonstrated the environmental benefits of protease use in chicken production because protein in the feed was reduced. Nielsen et al. [12] have demonstrated the environmental benefits of xylanase use in pig production because feed was saved and diet was changed. Bundgaard et al. [13] have demonstrated greenhouse-gas reductions in chicken production because feed composition was changed using a blend of xylanase, amylase, and protease. Documentation of environmental benefits is generally robust in the studies independently of considerable variation and uncertainty. Some of the important factors for variation are feed compositions, production practices, and growth stadiums of animals.

A recent study by Stefanello et al. [14] has shown that starch digestibility increases when the chickens' diet is supplemented with an amylase. This property of amylase is currently used to increase the energy value of starch-rich crops such as corn in commercial chicken production in Brazil because it allows for saving of costly fat in the diet.

The purpose of the present study is to assess environmental impact in a life cycle perspective of using an amylase as a factor for improving starch digestibility in chicken production. The study refers to a commercially available amylase (CAS 9000-90-2) called RONOZYME ${ }^{\circledR}$ HiStarch CT, produced by Novozymes A/S and brought to the market for direct use in the feed mix by DSM Animal Nutrition \& Health. RONOZYME ${ }^{\circledR}$ HiStarch CT was approved by the Brazilian Minister of Agriculture for poultry and swine production in Brazil in 2016.

\section{Materials and Methods}

\subsection{Analytical Framework}

Life cycle assessment (LCA) is an environmental assessment tool that can be used to assess and compare two or more solutions providing the same benefit for a user. LCA addresses all processes in the value chain, from raw material extraction through production and use to the final disposal. The present comparative study of conventional chicken feed without amylase use versus chicken feed with amylase use is conducted according to the ISO 14040 standards on LCA [15] using a market-based approach [16]. Modeling is facilitated in SimaPro 8.5.2 LCA software. Equivalency factors (for representing different emissions' relative contributions to various environmental impact categories) and normalization references (for comparing the magnitudes of different environmental impacts) are derived from the CML IA baseline method (version 3.05, 2017). Normalization data essentially represent total contributions to certain types of environmental impact in a specific region.

Feed compositions are modeled to meet nutritional needs for chicken at the lowest possible costs in the Optimal Formula 2000 feed optimization tool developed by Optimal Informatica. Feed compositions were based on feed raw material prices in 2016.

\subsection{Scope}

The function of the amylase is to break down starch, thereby improving the digestibility of starch, which can enable an adjustment of the composition of chicken feed. All calculations in the study refer to the production of one live broiler chicken at a slaughter weight of $2.0 \mathrm{~kg}$.

The study addresses intensive broiler chicken production in Brazil, where the diet is optimized to meet the requirements of the animal at the lowest-possible price and where the use of the amylase leads to specific changes in the feed composition determined in the above-mentioned feed optimization software. Small-holder and backyard chicken production are not in the scope of the assessment. 
The study addresses a conventional feed composition, where chicken fat is used as a fat source. A vegetarian feed, where the fat source is soybean oil, is assessed in sensitivity assessments. Cost aspects of amylase use in chicken production are not in the scope of the study.

\subsection{Choice of Impact Categories}

The following impact categories are influenced by amylase use in chicken production and included in this paper: climate change potential $\left(\mathrm{kg} \mathrm{CO}_{2}\right.$ equivalents, $\left.\mathrm{CO}_{2} \mathrm{e}\right)$, acidification potential $\left(\mathrm{kg} \mathrm{SO}_{2} \mathrm{e}\right)$, nutrient enrichment potential $\left(\mathrm{kg} \mathrm{PO}_{4} \mathrm{e}\right)$, fossil fuels consumption $(\mathrm{MJ})$, agricultural land use $\left(\mathrm{m}^{2}\right.$.year), and freshwater consumption (L. Other impact categories such as human toxicity, marine toxicity, terrestrial toxicity, stratospheric ozone depletion, and photochemical ozone formation were included in the background study. They are not reported here because the impact of the amylase on these categories turned out to be minor [15].

\subsection{Feed Composition Change}

A conventional optimized diet for chicken at the grower stage and the finisher stage with and without amylase is shown in Table 1. Adding the amylase to the feed makes more energy from starch in the corn accessible to the chicken, enabling costly chicken fat to be replaced with cheaper corn. Corn contains protein, and some soybean meal (SBM) is therefore also saved. The energy content $\left(3100 \mathrm{kcal} \mathrm{kg} \mathrm{feed}^{-1}\right)$ and nutrient value of the feed are maintained.

Table 1. Optimized chicken feed composition for grower and finisher stages with and without amylase application. Numbers are in \% of the total feed composition.

\begin{tabular}{ccccccc}
\hline \multirow{2}{*}{ Feed Ingredients } & \multicolumn{3}{c}{ Grower } & \multicolumn{3}{c}{ Finisher } \\
\cline { 2 - 7 } & $\begin{array}{c}\text { Without } \\
\text { Amylase }\end{array}$ & $\begin{array}{c}\text { With } \\
\text { Amylase }\end{array}$ & Change & $\begin{array}{c}\text { Without } \\
\text { Amylase }\end{array}$ & $\begin{array}{c}\text { With } \\
\text { Amylase }\end{array}$ & Change \\
\hline Corn & 62.19 & 64.03 & 1.84 & 66.66 & 68.30 & 1.64 \\
Soybean meal & 24.74 & 24.44 & -0.30 & 19.93 & 19.79 & -0.14 \\
Meat-bone meal & 2.00 & 2.00 & - & 1.50 & 1.50 & - \\
Poultry byproduct & 4.00 & 4.00 & - & 4.00 & 4.00 & - \\
Feather meal & 1.50 & 1.50 & - & 2.00 & 2.00 & - \\
Chicken fat & 3.52 & 1.97 & -1.55 & 3.77 & 2.25 & -1.52 \\
Soybean oil & - & - & - & - & - & - \\
Limestone & 0.80 & 0.80 & - & 0.88 & 0.88 & - \\
MCP & - & - & - & - & 0.36 & - \\
Salt & 0.35 & 0.35 & - & 0.36 & 0.23 & - \\
Methionine & 0.25 & 0.25 & - & 0.23 & 0.22 & - \\
Lysine & 0.20 & 0.20 & - & 0.22 & 0.04 & - \\
Threonine & 0.04 & 0.04 & - & 0.04 & 0.40 & - \\
Premix & 0.40 & 0.40 & - & 0.40 & - & - \\
Phytase & 0.01 & 0.01 & - & 0.01 & 0.013 & 0.013 \\
Amylase & - & 0.013 & 0.013 & - & 100 & - \\
\hline TOTAL * & 100 & 100 & - & 100 &
\end{tabular}

* May not sum up to exactly 100 due to rounding.

Conventional feed intake per live chicken at $2.0 \mathrm{~kg}$ slaughter weight is assumed to be $2050 \mathrm{~g}$ in the grower phase and $1150 \mathrm{~g}$ in the finisher phase, and total changes in feed composition per live chicken is shown in Table 2. 
Table 2. Change in chicken feed consumption per live chicken driven by using amylase. Plus (+) indicates that more of the ingredient is used, minus (-) indicates that less of the ingredient is used. All ingredients in the table are included in the study.

\begin{tabular}{cc}
\hline Feed Ingredient & Change Per Live Chicken $(\mathrm{g})$ \\
\hline Corn & $+56.55^{*}$ \\
SBM & -7.76 \\
Chicken fat & -49.3 \\
Amylase & +0.42 \\
\hline
\end{tabular}

* Example: The change in corn consumption per chicken is: $2050 \mathrm{~g} /$ chicken $1.84 \%+1150 \mathrm{~g} /$ chicken $1.64 \%=56.55 \mathrm{~g}$ corn per chicken.

\subsection{System Boundaries}

Animal fat from slaughterhouses is used for three main purposes in Brazil: animal feed (24\%), biodiesel production (38\%), and hygiene and cleaning products $(31 \%)$. The rest $(7 \%)$ is used for pet food, etc. [17]. The study addresses the two main alternative applications of the excess chicken fat, namely for biodiesel production (Scenario 1) or as a fat source for hygiene and cleaning products (Scenario 2). Scenario 1 is considered most likely because the use of animal fat for biodiesel has been growing in recent years. Scenario 2 is considered less likely because the use of animal fat for hygiene and cleaning products is declining.

The use of excess animal fat for biodiesel production (Scenario 1) saves fossil-based diesel and reduces fossil $\mathrm{CO}_{2}$ in the exhaust from diesel engines. The use of excess animal fat in hygiene and cleaning products (Scenario 2) will replace vegetable fat sources as other animal fat sources are constrained and will not react to a market change. Following Schmidt and Weidema [18], it is assumed that palm oil is the vegetable oil that ultimately reacts to the reduced demand for vegetable oil in hygiene and cleaning products. Saving animal fat in chicken feed is therefore ultimately assumed to save palm oil in Scenario 2. The chicken production process and output of live chicken is not assumed to be influenced by the use of the amylase because the input of feed in terms of energy and protein as well as output of chicken is constant. In the same way, the soap production process and combustion of diesel is not impacted. See Figure 1.

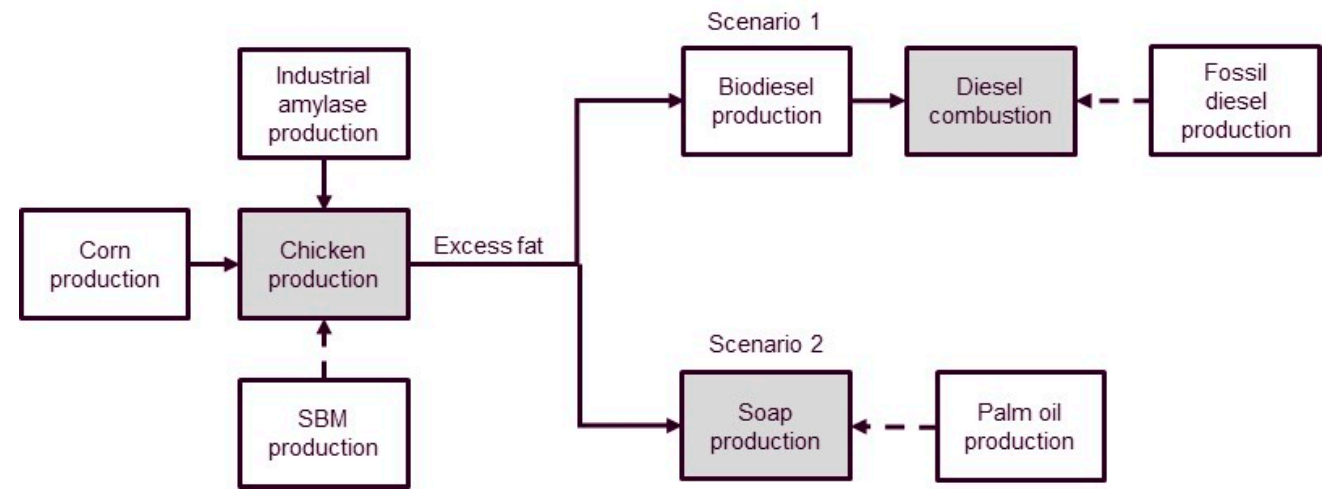

Figure 1. System boundaries of the study. Processes marked with white are impacted using the amylase in the chicken feed. Processes marked with gray are not impacted. Full arrows indicate induced production driven by amylase use. Dotted arrows indicate reduced production. The use of excess fat for biodiesel production and hygiene products is investigated in Scenario 1 and 2 respectively.

\subsection{Inventory}

The considered amylase is a granulated enzyme product produced by Novozymes. Modeling of the environmental impacts follows the concept described by Nielsen et al. [19] with a complete update of energy, raw material, and waste treatment data in 2015. The assessment of the product includes all 
heat, electricity, and water consumptions in production as well as waste management and $98 \%(w / w)$ of ingredients for the enzyme production. Modeling is based on enzyme production recipes from 2016.

Corn production has been modeled using a global corn production process from EcoInvent database [20] (Rest of the World, ROW). The corn production process starts after the harvest of the previous crop and includes the input of seeds, mineral fertilizers, pesticides, and irrigation. The dataset includes all machine operations and direct field emissions.

Soybean meal and palm oil production have been modeled in accordance with Schmidt [21]. Data includes all machine operations, fertilizers, and direct field emissions but not the use of pesticides. Coproducts are handled by system expansion in accordance with ISO 14040 [15].

Electricity supply is modeled using average grid data from the relevant regions [20]. Data includes fuel extraction, electricity production, and transmission.

Biodiesel is produced by the transesterification of excess chicken fat. Modeling is based on Jensen et al. [22] and includes all significant material and utility consumptions (excess chicken fat, methanol, potassium hydroxide, sulfuric acid, electricity, and heat) as well as coproduced glycerin. It is assumed that heat and methanol are produced from natural gas (fossil), that electricity is produced in Brazil (using Brazilian electricity mix), and that the produced biodiesel replaces fossil-based diesel. Coproduced glycerin is assumed to be used for heat production as a replacement for natural gas (fossil). The remains of potassium and sulfate from the biodiesel production process are assumed to be used in agriculture as a replacement for potassium sulfate fertilizer. The emission of $\mathrm{CO}_{2}$ from biodiesel combustion is considered neutral with respect to climate change, in contrast to the fossil-based diesel that it replaces. All secondary datas for biodiesel production are derived from the EcoInvent database [20].

\subsection{Transportation and Packaging}

The transportation of feed ingredients and raw materials to the final user is inherently included in raw material models [20]. The transportation and packaging of the amylase from production facilities to the Brazilian market is included based on data from Novozymes/DSM's logistics records. The amylase product is packed in $1000 \mathrm{~kg}$ recyclable woven polypropylene bags and transported in 20-metric-ton containers. Environmental impact of transportation (truck, ocean freighters) and packaging are based on data from the EcoInvent database [20].

\section{Results}

Changes in environmental impacts and resource consumptions when amylase is used in chicken feed are shown in Figures 2 and 3, representing Scenarios 1 and 2, respectively.

Figure 2 shows that fossil fuel consumption and contribution to climate change are reduced when the amylase is used as a supplement to chicken feed. This effect is primarily driven by the usage of excess chicken fat for biodiesel production and the consequent avoidance of fossil $\mathrm{CO}_{2}$ emission from the combustion of conventional diesel. Slightly increased net water consumption and contribution to nutrient enrichment is driven by increased corn consumption (irrigation and fertilizer use, respectively). Acidification and land use are not significantly influenced by using the amylase because different sources of impacts outweigh each other. The production, transportation and packaging of the amylase from the production site to the user are negligible for all considered impact categories.

Saved soybean meal (SBM) leads to a slightly increased contribution to climate change. The reason is that SBM production has soy oil as a coproduct and that reduced soy oil production leads to slightly increased palm oil production [21]. Palm oil production results in an increased contribution to climate change. 

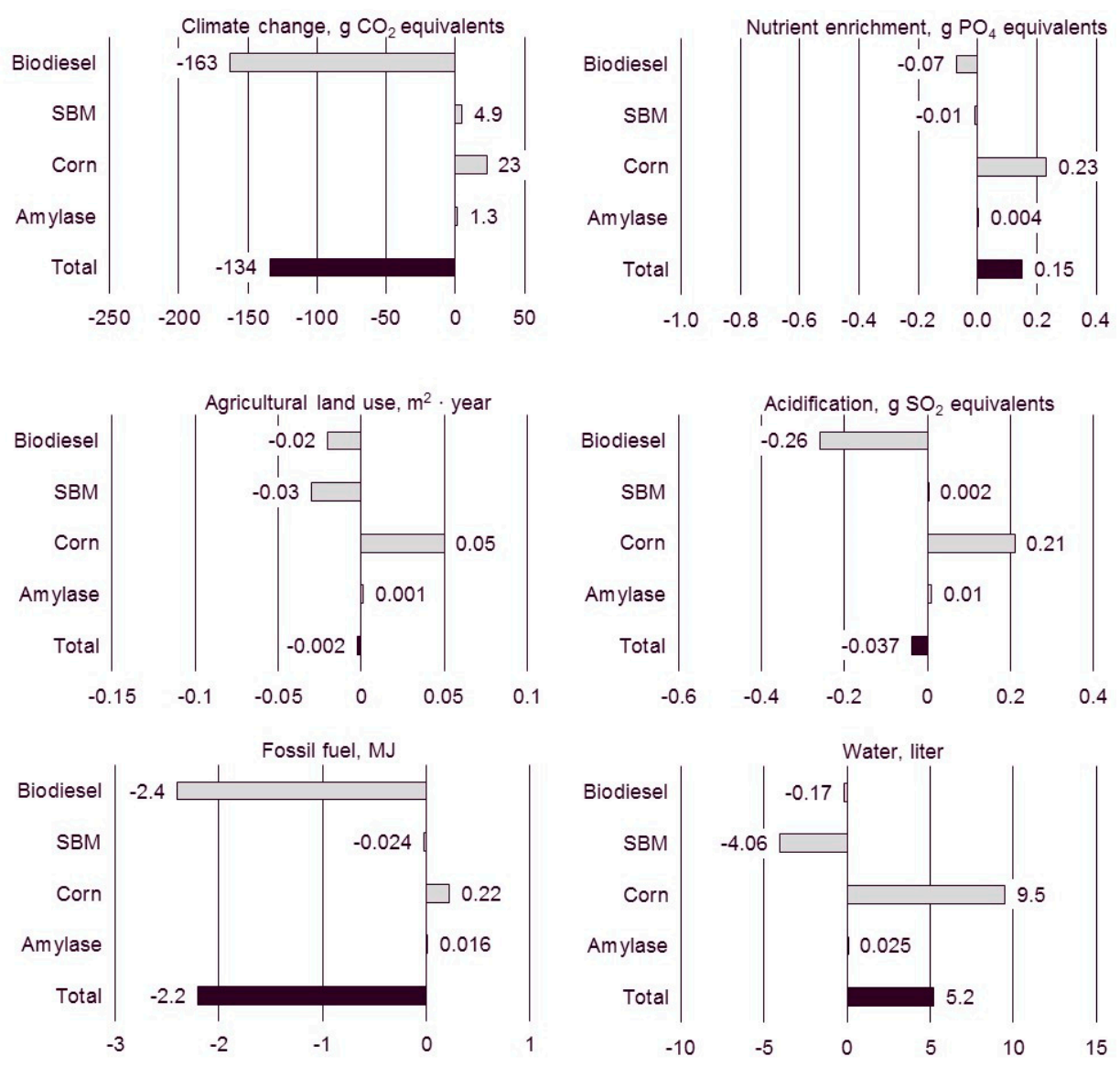

Figure 2. Changes in environmental impact and resource consumption when the amylase is added to chicken feed and reformulation of the feed leads to (1) increased corn consumption; (2) reduced soybean meal (SBM) consumption and (3) excess chicken fat is used for biodiesel production as alternative to conventional diesel (Scenario 1). Positive values indicate that an impact has increased. Negative values indicate that an impact has reduced. All data are per one live chicken $(2.0 \mathrm{~kg})$.

Figure 3 shows that the use of amylase reduces the contribution to climate change, nutrient enrichment and acidification, as well as agricultural land use when excess fat is used in hygiene and cleaning products. This is because the impact of producing the extra corn and soybean meal is minor compared with the impact of producing the saved palm oil. The use of amylase has a limited impact on fossil fuel consumption because energy requirements for producing the impacted crops are balancing each other out. The use of amylase drives five liters more water consumption per chicken because more water is used for the irrigation of corn.

Figure 2, Scenario 1, shows trade-offs between net reduced contributions to climate change and fossil fuel consumption on the one hand, and increased water consumption and contribution to nutrient enrichment on the other.

The observed environmental impacts have therefore been divided by the global impacts (normalization, see Figure 4) to make the different impacts comparable and to get an impression of the relative magnitudes. Agricultural land use and water consumption are not included because no normalization references are available.

Figure 4 shows that avoided contribution to climate change per chicken is approximately $3.2 \times 10^{-15}$ of the global contribution, whereas added contribution to nutrient enrichment is approximately $1.0 \times 10^{-15}$. This means that the relative decrease in contribution to global warming, for instance, is more than three times higher than the relative increase in contribution to nutrient enrichment. 

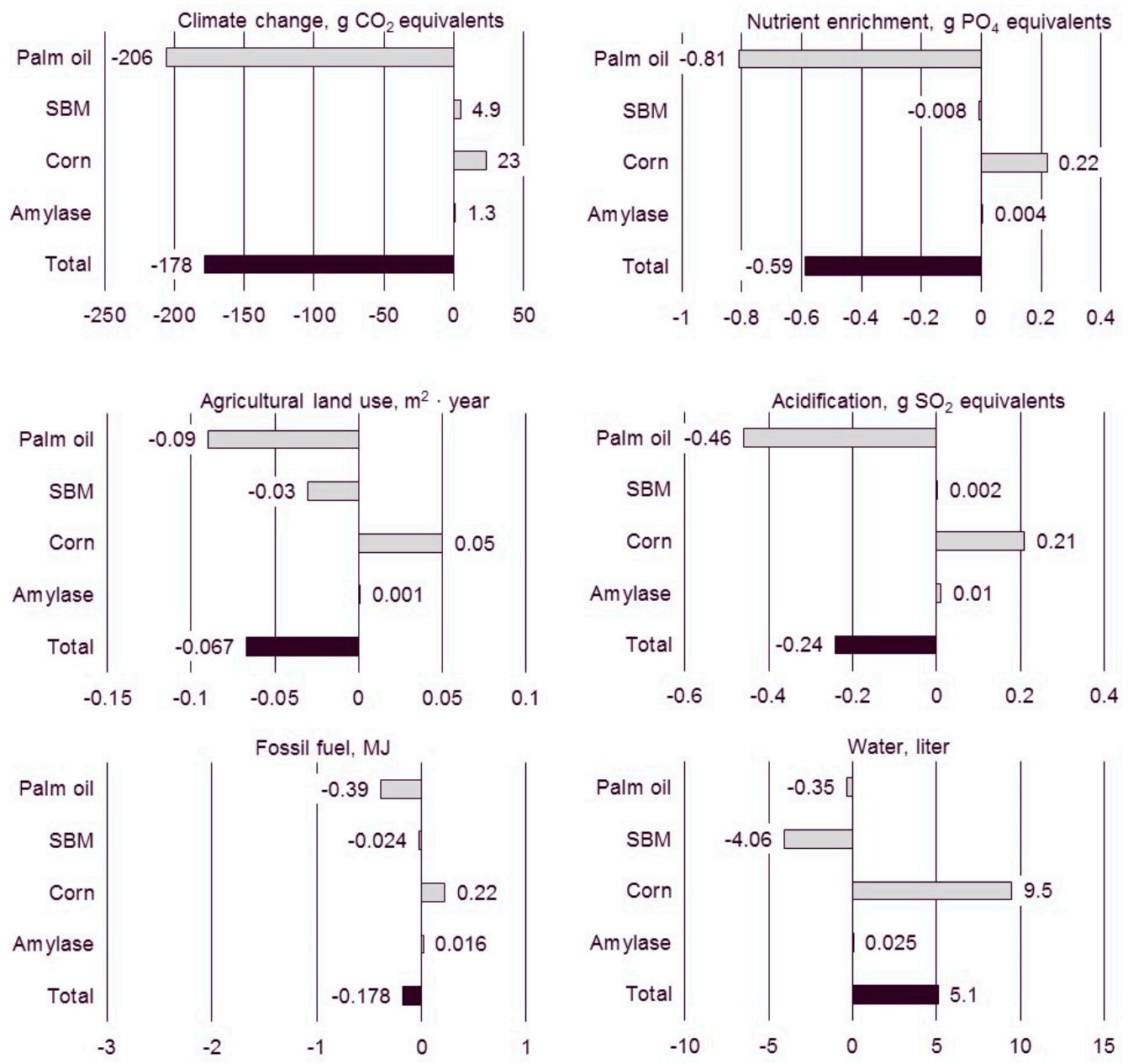

Fossil fuel, MJ
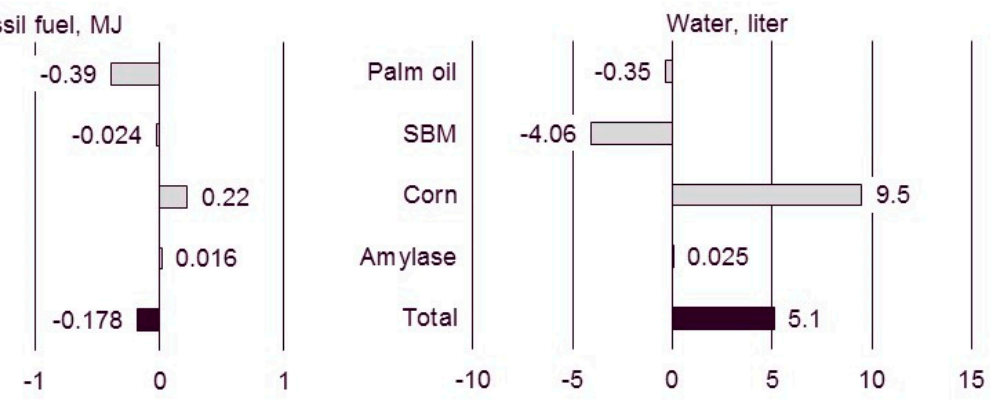

Figure 3. Changes in environmental impact and resource consumption when amylase is added to chicken feed and reformulation of the feed leads to (1) increased corn consumption; (2) reduced soybean meal and chicken fat consumption and (3) excess fat is used hygiene and cleaning products (Scenario 2) as alternative to vegetable oils-ultimately palm oil. Positive values indicate that an impact has increased. Negative values indicate that an impact has reduced. All data are per one live chicken $(2.0 \mathrm{~kg})$.

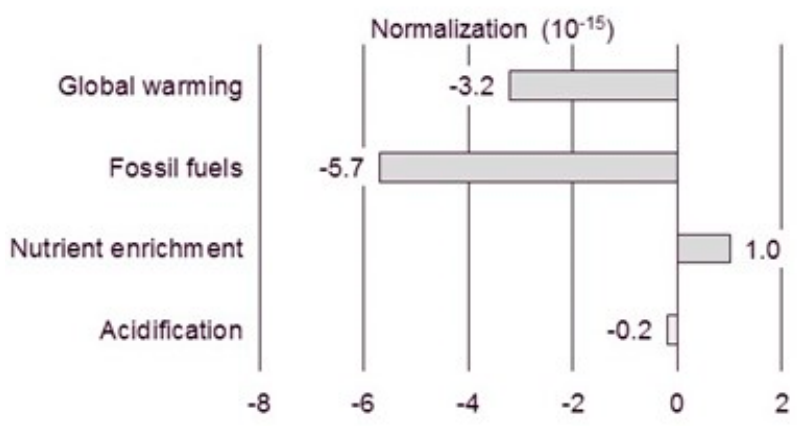

Figure 4. Normalized impact potentials of results from Scenario 1 where the use of amylase leads to animal fat savings and excess fat is used for biodiesel production. Positive values indicate a relative increase in contribution to the specific impact category. Negative values indicate a relative decrease.

\section{Data Quality Assessment}

Data quality assessment follows principles described by Weidema and Wesnæs [23], see Table 3. 
Table 3. Qualitative assessment of data quality and importance to the interpretation of the study. VG= Very good, G = Good, F = Fair and P = Poor.

\begin{tabular}{|c|c|c|c|c|c|c|c|c|}
\hline \multirow{2}{*}{ Process } & \multirow{2}{*}{ Data Source } & \multirow{2}{*}{ Comment } & \multicolumn{5}{|c|}{ Data Quality Indicators } & \multirow{2}{*}{ Importance } \\
\hline & & & Technology & Time & Geography & Completeness & Reliability & \\
\hline Enzyme production & [19] & $\begin{array}{l}\text { Modelling is based on Novozymes' } \\
2016 \text { production recipes and } 98 \% \\
\text { of raw materials are included }\end{array}$ & VG & VG & VG & VG & VG & Low \\
\hline Biodiesel production & {$[20,22]$} & $\begin{array}{l}\text { Modelling is based on a Danish } \\
\text { case study and may not represent } \\
\text { specific Brazilian conditions for } \\
\text { biodiesel production }\end{array}$ & G & $\mathrm{F}$ & $\mathrm{F}$ & G & VG & Low \\
\hline Palm oil production & {$[20,21]$} & $\begin{array}{l}\text { Modelling is based on a peer } \\
\text { reviewed publication }\end{array}$ & G & VG & $\mathrm{F}$ & G & VG & High \\
\hline Corn production & [20] & $\begin{array}{l}\text { Modelling is based on global data } \\
\text { and may not represent specific } \\
\text { Brazilian conditions for } \\
\text { corn production }\end{array}$ & G & G & $\mathrm{F}$ & G & G & Medium \\
\hline $\begin{array}{l}\text { Soybean meal } \\
\text { production }\end{array}$ & {$[20,21]$} & $\begin{array}{l}\text { Modelling is based on a peer } \\
\text { reviewed publication }\end{array}$ & G & VG & $\mathrm{F}$ & G & VG & Low \\
\hline $\begin{array}{c}\text { Fossil diesel and } \\
\text { natural gas production }\end{array}$ & [20] & Modelling is based on global data & G & G & $\mathrm{F}$ & G & G & Low \\
\hline
\end{tabular}


Table 3 shows that the data used in the study generally are considered reasonable and that data with medium or high importance for the outcome of the study are considered good or very good on all indicators except geography.

\section{Sensitivity Assessments}

Several assumptions and simplifications have been made during the study. The most important are subject to sensitivity analyses in the following to assess the robustness of the achieved results.

\subsection{Corn}

Corn production is modeled using a ROW process from the EcoInvent database [20], as this was judged to be the most representative for Brazil. To evaluate this choice, the impact of amylase in chicken production was modeled using a global corn production model and a corn production models representing the United States and Switzerland [20]. The results showed that the impact on climate change and acidification varied by a few percent, whereas the variations in the impact on nutrient enrichment and land use were negligible. Thus, using other corn production models does not seem to have any significant influence on the outcomes of the study.

\subsection{Marginal Vegetable Oil}

It has been assumed based on Schmidt and Weidema [18] that palm oil is the marginal vegetable oil that ultimately reacts to changes in fat consumption driven by using the amylase. It cannot be ruled out, however, that other bulk vegetable oils react to changes as well, and Scenario 2 has been carried out with rapeseed oil as the marginal vegetable oil. The results showed that the contribution to climate change was impacted by the change, whereas other impact categories were in the same range. Savings in greenhouse-gas emissions driven by amylase use were reduced from $178 \mathrm{~g} \mathrm{CO}_{2}$ equivalents when palm oil was the marginal oil to $9.5 \mathrm{~g}$ per chicken when rapeseed oil was assumed to be the marginal vegetable oil. The reason is that many palm oil plantations (in contrast to rapeseed oil plantations) are located on peat land, and a considerable amount of $\mathrm{CO}_{2}$ from degrading peat is escaping the fields [21].

\subsection{Feed Prices}

Feed is optimized to meet chickens' nutritional requirements at the lowest-possible price in industrial chicken production in Brazil [24], and relative changes in feed prices could potentially influence the diet and thus the impact of using the amylase. The gross amounts of corn, SBM, and fat in Brazilian chicken feed are independent of variation in prices, however, the inclusion of amylase in the feed is therefore considered price-independent.

\subsection{Soy Oil as a Fat Source for Chicken Feed}

Soy oil is also used as a fat source in chicken feed in Brazil, and the entire assessment has been made in two cases where the use of amylase leads to soy oil saving and excess soy oil is used for biodiesel production (as in Scenario 1 above) or hygiene and cleaning products (as in Scenario 2). It was again assumed that biodiesel is used as a replacement for fossil diesel and that the ultimate impact of using a new type of fat in hygiene and cleaning products is palm oil saving (soy oil production is driven by soybean meal production and thus constrained). The results showed that the use of amylase on the vegetarian diet with soy oil as a fat source led to nearly the same result on all considered impact categories as when amylase was used on a non-vegetarian diet with chicken fat. The reason is that the diet was nearly the same (except the different sources of fat), and that chicken fat and soy oil have the same value as feed stock for biodiesel and hygiene/cleaning products, respectively. The same is likely to be the case for other fat sources, and the study appears to be robust to variations in fat source for the chickens' feed. 


\subsection{Amylase Efficiency}

Modelling of feed composition with amylase added (see Table 1) refers to a specific efficiency of the enzyme. Even though the efficiency of the amylase product is considered fixed for the considered production system, it could be interesting to see how results would change if efficiency of the amylase hypothetically was different. Modelling was therefore repeated assuming $10 \%$ higher and $10 \%$ lower efficiency of the amylase. The result showed that $10 \%$ percent more efficiency of the enzyme led to $9-14 \%$ more environmental impact reduction (depending on impact category) and that $10 \%$ less efficiency of the enzyme led to $9-14 \%$ less environmental impact reduction.

\section{Discussion}

The present study has shown that the use of amylase in intensive chicken production in Brazil reduces the contribution to a broad range of environmental impact categories. Exceptions are water consumption (approximately five liters of water per live chicken) and contribution to nutrient enrichment ( $0.15 \mathrm{~g} \mathrm{PO}_{4}$ equivalents per live chicken) when excess chicken fat is used for biodiesel production.

González-García et al. [25] have studied cradle-to-farm gate impact of chicken production and found greenhouse-gas emission in the order of $2.4 \mathrm{~kg} \mathrm{CO}_{2} \mathrm{e}$ per live chicken (average of several studies) and nutrient enrichment in the order of $24 \mathrm{~g} \mathrm{PO}_{4}$ e per live chicken. The relative saving in greenhouse-gas emission achieved using the amylase is therefore estimated to be $\left((0.134+0.178) / 2 \mathrm{~kg} \mathrm{CO}_{2} \mathrm{e}\right.$ per live chicken $/ 2.4 \mathrm{~kg} \mathrm{CO} 2 \mathrm{e}$ per live chicken) $\sim 6 \%$, whereas the relative increase in nutrient enrichment when the fat is used for biodiesel production is estimated to be $\left(0.15 \mathrm{~g} \mathrm{PO}_{4} \mathrm{e} / 24 \mathrm{~g} \mathrm{PO}_{4} \mathrm{e}\right) \sim 0.6 \%$.

Furthermore, normalization of the results (Figure 4) revealed that the relative decrease in the contribution to global warming was approximately three times higher than the relative increase in contribution to nutrient enrichment, indicating that the use of the enzyme is generally an environmental benefit despite the trade-off.

Chicken production uses thousands of liters of water per kg of meat [26], and the trade-off at $5 \mathrm{~L}$ of extra water consumed per live chicken driven by amylase use is therefore considered insignificant.

Sensitivity assessments have shown that the results of the study are generally robust because variations in the most significant and uncertain data and assumptions do not change the outcomes of the study notably. A single exception is the assumption about how vegetable oil reacts to changes in the edible fat market. Results would be less favorable in terms of climate change if the marginal vegetable oil were rapeseed oil or any other oil with less impact on climate change than palm oil.

\section{Conclusions}

The present study shows that the use of amylase to increase the digestibility of starch in chicken feed in Brazil is justified by the considerable benefits in terms of a reduced contribution to climate change when saved chicken fat or soybean oil is used for biodiesel or for replacing other oils in hygiene and cleaning products. The use of amylase has no significant impact on agricultural land use or acidification but a considerable saving in fossil fuel when the amylase enables increased biodiesel production. The use of amylase increases nutrient enrichment and water consumption for chicken production insignificantly compared with the benefits in terms of reductions in greenhouse-gas emissions. Outcomes of the study are sensitive to changes in the fat market but are otherwise robust.

\section{Perspectives}

The use of amylase saves on average $134 \mathrm{~g} \mathrm{CO}_{2}$ equivalents per live chicken if Scenario 1 (production of biodiesel) applies and on average $178 \mathrm{~g} \mathrm{CO}_{2}$ equivalents per live chicken if Scenario 2 (palm oil saving) applies. Approximately $5.6 \times 10^{9}$ chickens were produced in Brazil in 2013 [27]. Thus, if amylase were applied to all chickens in Brazil, the total reduction in contribution to climate 
change would amount to approximately 0.75 to 1 million metric tons $\mathrm{CO}_{2}$ e annually $(\sim 900,000$ metric tons $\mathrm{CO}_{2}$ e annually on average).

The most important factors for the outcome of this study in Brazil are (1) the enzyme's effect on starch in the feed; and (2) alternative uses of the saved fat. Starch and fat are the major energy sources in chicken feed globally, and the impact of the enzyme would most likely be similar in other geographies in the world. Fat could be combusted and used for energy purposes in other countries, but otherwise uses and effects of the saved fat would most likely be the same. Using saved fat in energy supply via combustion as an alternative to the biodiesel pathway would result in similar greenhouse-gas savings (energy value considerations), and it is likely that the overall observations in the study would be valid for intensive chicken production globally.

The present study has focused on amylase for chicken production and interpretation of the results are restricted to this animal group. Additional studies will be needed to address environmental impacts of amylase for other animal groups.

Author Contributions: Conceptualization, B.G. and P.H.N.; Methodology, B.G.; Validation, B.G., P.H.N. and J.O.B.S.; Formal Analysis, B.G.; Investigation, B.G.; Resources, J.O.B.S.; Data Curation, B.G.; Writing-Original Draft Preparation, P.H.N.; Writing-Review \& Editing, B.G.; Visualization, B.G.; Supervision, P.H.N.; Project Administration, B.G.

Funding: This research received no external funding.

Acknowledgments: The authors are grateful to Anders Schmidt, Senior Project Manager at FORCE Technology in Denmark for reviewing the background LCA study according to ISO 14040 series and to José Fernando Machado Menten, Animal Science Department, University of São Paulo, Brazil, for providing input to sections about chicken feed and for reviewing the applied data.

Conflicts of Interest: The authors are employed by Novozymes or DSM Nutritional Products and have an interest in promoting the use of enzymatic solutions because the companies innovate, produce, and market enzymes for industrial use.

\section{References}

1. Steinfeld, H.; Gerber, P.; Wassenaar, T.; Castel, V.; Rosales, M.; de Haan, C. Livestock's Long Shadow: Environmental Issues And Options; Food and Agriculture Organization of the United Nations: Rome, Italy, 2006.

2. Gerber, P.J.; Steinfeld, H.; Henderson, B.; Mottet, A.; Opio, C.; Dijkman, J.; Falcucci, A.; Tempio, G. Tackling Climate Change through Livestock: A Global Assessment of Emissions and Mitigation Opportunities; Food and Agriculture Organization of the United Nations: Rome, Italy, 2013.

3. OECD/FAO. OECD-FAO Agricultural Outlook 2014; OECD Publishing: Paris, France, 2014.

4. MacLeod, M.; Gerber, P.; Mottet, A.; Tempio, G.; Falcucci, A.; Opio, C.; Vellinga, T.; Henderson, B.; Steinfeld, H. Greenhouse Gas Emissions from Pig and Chicken Supply Chains: A Global Life Cycle Assessment; Food and Agriculture Organization of the United Nations: Rome, Italy, 2013.

5. Aehle, W.; Perham, R.N.; Michal, G.; Caddow, A.J.; Concoby, B. Enzymes, 1. General. In Ullmann's Encyclopedia of Industrial Chemistry; Wiley-VCH Verlag GmbH \& Co. KGaA: Weinheim, Germany, 2008.

6. Demain, A.L.; Fang, A. The Natural Functions of Secondary Metabolites. In History of Modern Biotechnology I; Scheper, T., Fiechter, A., Eds.; Springer: Berlin, Germany, 2000.

7. Jegannathan, K.R.; Nielsen, P.H. Environmental Assessment of Enzyme Use in Industrial Production: A Literature Review. J. Clean. Prod. 2013, 42, 228-240. [CrossRef]

8. Herbots, I.; Kottwitz, B.; Reilly, P.J.; Antrim, R.L.; Burrows, H.; Lenting, H.B.M.; Viikari, L.; Suurnäkki, A.; Niku-Paavola, M.-L.; Pere, J.; et al. Enzymes, 4. Non-food Application. In Ullmann's Encyclopedia of Industrial Chemistry; Wiley-VCH Verlag GmbH \& Co. KGaA: Weinheim, Germany, 2008.

9. Nielsen, P.H.; Wenzel, H. Environmental Assessment of Ronozyme P5000 CT Phytase as an Alternative to Inorganic Phosphate Supplementation to Pig Feed Used in Intensive Pig Production. Int. J. Life Cycle Assess. 2007, 12, 514-520. [CrossRef]

10. Oxenbøll, K.M.; Pontoppidan, K.; Fru-Nji, F. Use of a Protease in Poultry Feed Offers Promising Environmental Benefits. Int. J. Poult. Sci. 2011, 10, 10-842. 
11. Leinonen, I.; Williams, A.G. Effects of Dietary Protease on Nitrogen Emissions from Broiler Production: A Holistic Comparison Using Life Cycle Assessment. J. Sci. Food Agric. 2015, 95, 3041-3046. [CrossRef] [PubMed]

12. Nielsen, P.H.; Dalgaard, R.; Korsbak, A.; Pettersson, D. Environmental Assessment of Digestibility Improvement Factors Applied in Animal Production: Use of Ronozyme WX CT Xylanase in Danish Pig Production. Int. J. Life Cycle Assess. 2008, 13, 49-56.

13. Bundgaard, A.M.; Dalgaard, R.; Gilbert, C.; Thrane, M. Assessment of the Potential of Digestibility-Improving Enzymes to Reduce Greenhouse Gas Emissions from Broiler Production. J. Clean. Prod. 2014, 73, 218-226. [CrossRef]

14. Stefanello, C.; Vieira, S.L.; Santiago, G.O.; Kindlein, L.; Sorbara, J.O.; Cowieson, A.J. Starch Digestibility, Energy Utilization, and Growth Performance of Broilers Fed Corn-Soybean Basal Diets Supplemented with Enzymes. Poult. Sci. 2015, 94, 94-2472. [CrossRef] [PubMed]

15. Gernaey, B. Life Cycle Assessment of Addition of HiStarch to Chicken Feed in Brazil; Novozymes A/S Internal Report; Novozymes: Bagsværd, Denmark, 2016.

16. Ekvall, T.; Weidema, B.P. System Boundaries and Input Data in Consequential Life Cycle Inventory Analysis. Int. J. Life Cycle Assess. 2004, 9, 161-171. [CrossRef]

17. ABRA. II Diagnóstico da Reciclagem Animal Brasileira; Associação Brasileira de Reciclagem Animal: Brasília, Brazil, 2016.

18. Schmidt, J.H.; Weidema, B.P. Shift in the Marginal Supply of Vegetable Oil. Int. J. Life Cycle Assess. 2008, 13, 235-239. [CrossRef]

19. Nielsen, P.H.; Oxenbøll, K.M.; Wenzel, H. Cradle-to-gate Environmental Assessment of Enzyme Products Produced Industrially in Denmark by Novozymes A/S. Int. J. Life Cycle Assess. 2007, 12, 432-438. [CrossRef]

20. The EcoInvent Organisation. EcoInvent Life Cycle Inventory Database; The EcoInvent Organisation: Zurich, Switzerland, 2014.

21. Schmidt, J.H. Life Cycle Assessment of Five Vegetable Oils. J. Clean. Prod. 2015, 87, 130-138. [CrossRef]

22. Jensen, K.H.; Thyoe, K.A.; Wenzel, H. Life Cycle Assessment of Bio-Diesel from Animal Fat-Report for Daka a.m.b.a, Ringsted; Institute for Product Development, Technical University of Denmark: Copenhagen, Denmark, 2007.

23. Weidema, B.; Wesnæs, M.S. Data Quality Management for Life Cycle Inventories: An Example of Using Data Quality Indicators. J. Clean. Prod. 1996, 4, 167-174. [CrossRef]

24. Rostagno, H.S.; Albino, L.F.T.; Donzele, J.L.; Gomes, P.C.; Oliveira, R.F.; Lopes, D.C.; Ferreira, A.S.; Barreto, S.L.T.; Euclides, R.F. Tabelas Brasileiras Para Aves e Suínos: Composição de Alimentos e Exigências Nutricionais de Aves e Suinos, 3rd ed.; Universidade Federal de Vicosa: Viçosa, Brazil, 2011.

25. González-García, S.; Gomez-Fernández, Z.; Dias, A.C.; Feijoo, G.; Moreira, M.T.; Arroja, L. Life Cycle Assessment of Broiler Chicken Production: A Portuguese Case Study. J. Clean. Prod. 2014, 74, 125-134.

26. Hoekstra, A.Y. The Water Footprint of Modern Consumer Society; Routledge Taylor \& Francis Group (Earthscan): London, UK; New York, NY, USA, 2013.

27. FAOSTAT. Food and Agriculture Data; Food and Agriculture Organization of the United Nations, Statistics Division: Rome, Italy, 2016.

(C) 2018 by the authors. Licensee MDPI, Basel, Switzerland. This article is an open access article distributed under the terms and conditions of the Creative Commons Attribution (CC BY) license (http:/ / creativecommons.org/licenses/by/4.0/). 